\title{
Method of Land Cover Change and Number of Vehicles Increasing on Land Surface Temperature: Case Research of Surabaya City, East Java Province, Indonesia
}

\author{
Mohammad Abdul Khafid, Aditya Pandu Wicaksono, Bayu Elwantyo Bagus Dewantoro
}

\begin{abstract}
Urban Heat island phenomenon that occurs in some major cities to Indonesia can be caused by several factors like a construction of high building, land cover change and air pollution by motor vehicles. The phenomenon of small climate change in urban areas such as the city of Surabaya, the province of Jawa Timur can cause rising surface temperatures that can impact the decline in health and environmental degradation. This research was conducted to know the dynamics of land cover change, and dynamics of the vehicle to surface temperature in Surabaya city. Methods that are in use are a spatial analysis of multi-temporal imagery and analysis by using statistical data. The data used in surface temperature analysis and land cover analysis in the form of vegetation is Landsat-8 (OLI/TIRS) during the recording period from 2014 to 2019 and vehicle dynamics data. The results showed a change of land cover with an estimated area of 2989,8 ha, a rise in surface temperature with an estimate of $3.95^{\circ} \mathrm{C}$, and with the increase in a several of vehicles by 929.225 units from 2013 until 2018. Large surface temperature shows the areas with crowded activities such as settlements area, industrial zone, and government zone.
\end{abstract}

Keywords : Urban Heat Island, Land Cover Change, Number of Vehicles, Land Surface Temperature

\section{INTRODUCTION}

The phenomenon of the occurrence of microclimate change is strongly influenced by human activities that continue to reduce the surface of the earth's vegetation that causes the environment to change mainly into terrestrial ecosystems in the urban or local scale that Specifically characterized by increased surface temperature [1]. The rapid development of the city with increasingly dense population conditions, build-up areas or settlements that tend to be more widespread, as well as the more complete transportation facilities of the city as a supporting economic and social activities, caused the condition surface temperature in cities is higher compared to the surrounding

Revised Manuscript Received on January 10, 2020.

* Correspondence Author

Mohammad Abdul Khafid*, Department of Environmental Engineering, Faculty of Mineral Technology, Universitas Pembangunan Nasional Veteran Yogyakarta, Yogyakarta, Indonesia. Email: abdulkhafid925@gmail.com

Aditya Pandu Wicaksono, Department of Environmental Engineering, Faculty of Mineral Technology, Universitas Pembangunan Nasional Veteran Yogyakarta, Yogyakarta, Indonesia. Email: aditya.wicaksono@upnyk.ac.id

Bayu Elwantyo Bagus Dewantoro, Department of Geographic Information Science, Faculty of Geography, Universitas Gadjah Mada, Yogyakarta, Indonesia. Email: bayuelwantyo@mail.ugm.ac.id region or urban heat island [2]. The condition of surface temperature dynamics that continue to increase to while can be caused by the presence of exhaust emission of motor vehicles, industrial, and change from land covered. The land-use change factor will directly affect the evaporation rate, absorption of solar radiation, heat storage, the thermal transmission of soil, and earth temperature surface temperature [3]. This also resulted in changes in atmospheric composition that were near the surface, water balance, and process of environmental interaction in urban areas that directly also lowered the level of urban public health [1]. The dynamics of motor vehicles for the urban areas that each year increase can decrease air quality of leave by the emission of exhaust gases like a lead (PB), carbon dioxide $\left(\mathrm{CO}_{2}\right)$, carbon monoxide (CO), hydrocarbon (HC), Nitrogen oxide (NO), and Sulfur dioxide $\left(\mathrm{SO}_{2}\right)$ which could have an impact on changes in atmospheric composition. Carbon dioxide $\left(\mathrm{CO}_{2}\right)$ is one type of pollutant that is the most atmospheric in the atmosphere that is produced by motor vehicles and makes the layer of atmospheric more thickened [4].

The changes in the microclimate as well as the global consequences of increasing exhaust emissions in the atmosphere significantly affect climate variation in a long time. A considerable amount of carbon dioxide gas in urban environments generated by transportation activities can cause a greenhouse gas effect on the balance of radiation energy in the troposphere and surface temperature earth [5]. The dynamics of surface temperature in urban areas generally align with the growth conditions of urbanization, industrialization, economic and social pace.

Urban areas in East Java with the high economic growth rate are Surabaya City that serves as the center of government in the East Java Province. Surabaya City as the center of government, industry and economic activities resulted in the increase of land use and air pollution by motor vehicle activities. Changes in land cover of unawakened land or vegetation into awakened land or alignment with the use of building materials that that have good heat absorbent ability and with low albedo causing the surface temperature to rise. The analysis of vegetation density, motor vehicle dynamics, and surface temperature should be carefully examined, associated with the urban buffer system. The observation of vegetation density, vehicle dynamics, and surface temperature can be a remote sensing data with multi-temporal and multi-spectral resolutions 
that combine with qualitative statistical analyses of motor vehicles dynamics [6].

Land Surface Temperature (LST) estimate study from the infrared (band) sensor is analyzed mathematically to determine the value of radians, while the value of vegetation density data is retrieved by means of the Normalized Vegetation Difference Index (NDVI) method of statistical relations between NDVI from visible/infrared bands (NIR) and emissivity in infrared band wavelength [7]. These three pieces of information will be used to analyze the causal factors of urban heat island phenomena in urban areas. Therefore, the purpose of this study is to know cause that affected dynamics of surface temperature in Surabaya city from $2014-2019$.

\section{LOCATION AREA}

Surface temperature studied located in Surabaya city which is the government capital of East Java Province, Indonesia. The region is geographically located at the coordinates of at $07^{\circ} 09^{\prime} 00^{\prime \prime}-07^{\circ} 21^{\prime} 00^{\prime \prime}$ (SL) and 112 ${ }^{\circ} 36^{\prime}-112^{\circ} 54^{\prime}(\mathrm{EL})$. The city has a large enough area of 326.81 $\mathrm{km}^{2}$ which is divided into 31 districts and 154 villages with a population of more than 3 million inhabitants. The city has a tropical climate of an average rainfall of $165.3 \mathrm{~mm}$. Conditions in wet months such as January-March and November-December, rainfall intensity can touch the highest point of more than $200 \mathrm{~mm}$ with air temperatures that range from $23.6^{\circ} \mathrm{C}-33.8^{\circ} \mathrm{C}[8]$.

\section{RETRIEVAL DATA SOURCE}

The process of surveying the vegetation density and surface temperature data is done by utilizing satellite data imagery Landsat-8 (OLI/TIRS) obtained from (USGS) with a sampling location in Surabaya City. Detailed information about Landsat-8 (OLI/TIRS) characteristics used, seen in Table-I. The shooting period was done for 6 years namely with a selection of data source retrieval times based on cloud cover conditions, region spatial parameters, temporal resolution, data availability and spectral resolution. One of the most complete of Landsat satellite imagery is the intermediate spatial resolution which is suitable for use of city-scale and accessible. Analysis of increasing motor vehicles for the do descriptively with data obtained from the BPS Surabaya city and BAPENDA Provinsi Jawa Timur from 2013 years to 2018 years [8], [9]. While the air quality data is getting from DIKPLHD Provinsi Jawa Timur.

Table-I. Specification of Landsat-8 (OLI/TIRS) imagery.

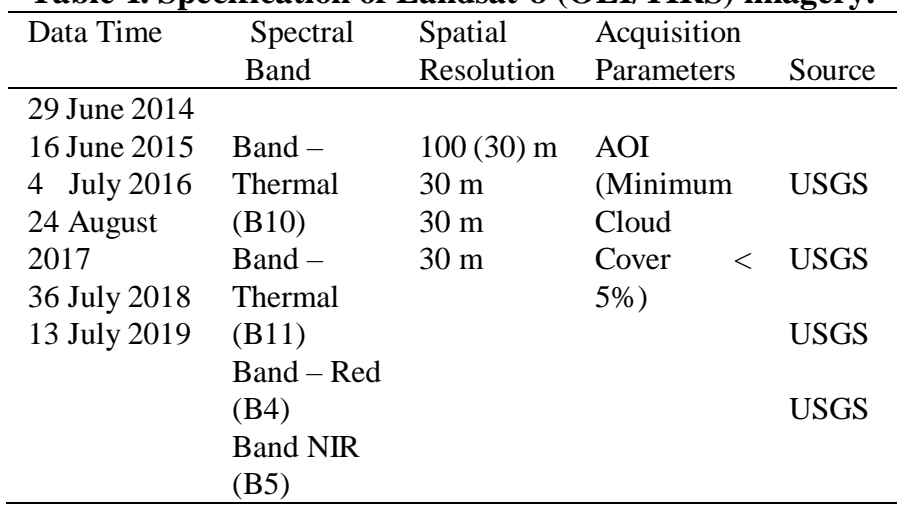

\section{DATA RETRIEVAL ANALYSIS TECHNIQUES OF LST AND NDVI}

Analysis of the characteristic phenomenon of urban heat island in urban areas, LST becomes an important part of the heat transfer modeling of vegetation-atmospheric-soil in the dynamic ecosystem of terrestrial environments [10]. Software used in data analysis and image processing using ESRI Software ${ }^{\circledR} \operatorname{ArcMap}^{\mathrm{TM}}$ v. 10.3 and IBM SPSS ${ }^{\circledR}$ software. The digital number conversion to imagery becomes TOA radiance [11], with the equation formula:

\section{$L \lambda=M L \times Q c a l+A L$}

The TOA radiance conversion becomes a kinetic temperature (LST) with Kelvin temperature units, the equation of the formula:

$$
T=\frac{K 2}{\operatorname{Ln}\left(\frac{K 1}{L \lambda}+1\right)}
$$

Kinetic $\mathrm{T}$ Conversion in Kelvin to Celsius unit with equation formula:

\section{$($ T kinetic Celsius $=T-273.15)$}

The vegetation density value is determined by NDVI indexes with classifying range of values-0.40-0 (body water), $0-0.2$ (land awakened low density), $0.2-0.4$ (mixed vegetation) and $>0.4$ (full vegetation) [12]. NDVI vegetation index Formula [13] :

$$
N D V I=\frac{N I R B \text { and }-\operatorname{Re} d B \text { and }}{N I R B \text { and }+\operatorname{Re} d B \text { and }}
$$

Calculation of LST and NDVI correlation values refers to the following two-equation formulas.

$$
\begin{gathered}
\operatorname{Cov}(i, j)=\frac{(Z i k-\mu i)-(Z j k-\mu j)}{N-1} \\
\operatorname{Corr}(i, j)=\frac{\operatorname{Cov}(i, j)}{\delta i \delta j}
\end{gathered}
$$

Data significance testing is done using the T-test method, where data is rated significantly when $\mathrm{T}$-count $>\mathrm{T}$-table [14].

\section{CORRELATION ANALYSIS}

Data correlation is done qualitatively descriptive with the analysis of the relationship between vegetation density data, the dynamic number of motor vehicles, air quality of three sampling points and surface temperature dynamics in Surabaya city. The number of vehicles data used from the year 2013 to 2018, while the air quality of the city of Surabaya is taken at three points location is Jl. A. Yani Surabaya, Perum Medokan Asri Utara Surabaya, and Rungkut Industri Raya Surabaya [15]. 


\section{RESULT AND DISCUSSION}

Retrieval of Surface temperature data (LST) and NDVI in the city of Surabaya, East Java Province using Landsat-8 (OLI/TIRS) imagery with the period of captured is 29 June 2014, 16 June 2015, 4 July 2016, 24 August 2017, 36 July 2018 and 13 July 2019. The period of image captured based on the main parameters is small cloud cover and data availability. The result of a spatial distribution pattern of vegetation density and surface temperature in the city of Surabaya in years $2014-2019$ can be seen in (Fig. 1.). The result of vegetation density showed in 2014-2019 Surabaya City showed very dynamic.

The highest concentrations of vegetation density (NDVI) occurred in 2014 with vegetation density (NDVI > 0.4) amounting to $37,24 \%$ of the total area of the region with an area of 12,114.54 ha. While in 2018 there was a significant decline in high vegetation density of only about $23,97 \%$ with an area of 7,799.58 ha. The period in 2019 increased by $4.07 \%$ with an area of 9124.74 ha. The dynamics of land use of Surabaya city is very fast in the area of residents and cities such as Simokerto district, Krembangan district, Sawahan district and industry area in Rungkut district.

The spatial distribution pattern of surface temperature (LST) of Surabaya City (Fig. 1.), is seen fluctuating temperature change and tends to increase from 2014 to 2019. The lowest surface temperature occurred in 2014 with an average temperature of $22.41{ }^{\circ} \mathrm{C}$ and an area reaching $88 \%$ or 29452.59 ha. The highest surface temperature occurred in 2018 with an average temperature of $35.92{ }^{\circ} \mathrm{C}$ with an average increase of each year by $3.95{ }^{0} \mathrm{C}$. Regions with temperatures ranging from $25-27{ }^{\circ} \mathrm{C}$ are in areas with low density and motor vehicle activity in some districts including Mulyorejo, Sukolilo, Rungkut, and Gunung Anyar. For more information see in (Table-II).

The ratio of the motor vehicles each year continues to increase from $2014-2019$ by 929,225 units, with the highest number of vehicles being in the period 2018 reaching $2,729,640$ units, which can be seen in (Fig. 2.). The increasing intensity of motor vehicles resulted in the amount of gas in the atmospheric layer. Measurement of air quality is done with three sampling points located in settlements (Medokan Asri, Rungkut District), roadside (JL. Ahmad Yani, Gayungan District), and area industry (Rungkut Raya, Rungkut District) with parameters $\mathrm{CO}, \mathrm{SO}_{2}, \mathrm{NO}_{2}, \mathrm{TSP}, \mathrm{O}_{3}$, and PM10. The number of concentrations of $\mathrm{CO}_{2}, \mathrm{NO}_{2}$ and TSP (Total Suspended Particulate) occupies the highest order on the roadside location (JL. Ahmad Yani, Gayungan District) amounted to $22,376 \mu \mathrm{g} / \mathrm{Nm}^{3}, 8.9222,376 \mu \mathrm{g} / \mathrm{Nm}^{3}$ and $781.6 \mu \mathrm{g} / \mathrm{Nm}^{3}$. The highest concentrations of $\mathrm{O}_{3}, \mathrm{SO}_{2}$ and PM10 are in settlement areas (Medokan Asri, Rungkut) with values of $40.7 \mu \mathrm{g} / \mathrm{Nm}^{3}, 14.9 \mu \mathrm{g} / \mathrm{Nm}^{3}$, and 110.03 $\mu \mathrm{g} / \mathrm{Nm}^{3}$ [15].

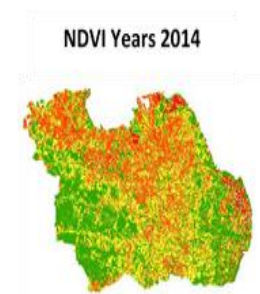

NDVI Years 2017

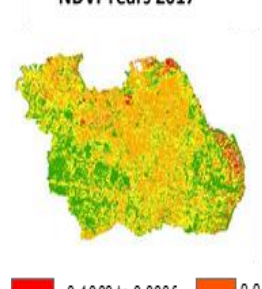

-0.4000 to 0.0006

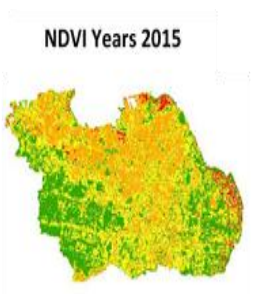

NDVI Years 2018

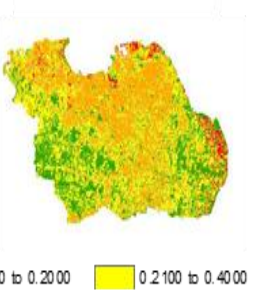

NDVI Years 2016

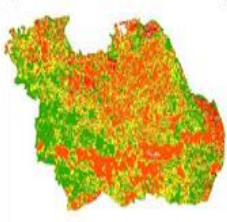

NDVI Years 2019

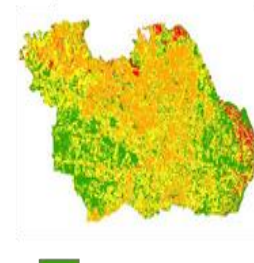

LST Years 2014

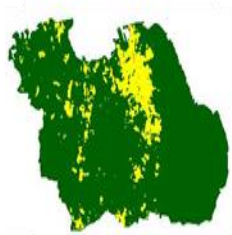

LST Years 2017

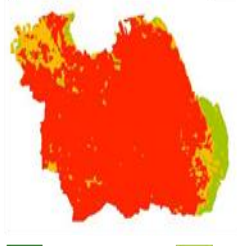

LST Years 2015

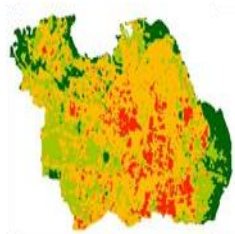

LST Years 2018

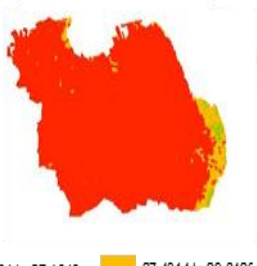

LST Years 2016

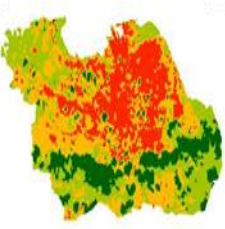

LST Years 2019

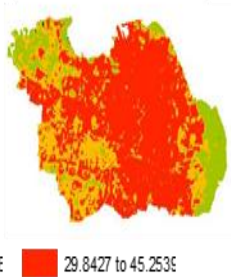

Fig. 1. Spatial distribution of NDVI and LST in Surabaya City

Table-I: Data of minimum, maximum, average and standard deviation values of LST and NDVI

\begin{tabular}{ccccccccc}
\hline & \multicolumn{3}{c}{ NDVI } & \multicolumn{5}{c}{ LST } \\
\hline Years & Min & Max & Average & Std.Dev & Min & Max & Average & Std.Dev \\
2014 & $-1,00$ & 1,00 & 0,34 & 0,22 & 13,06 & 28,17 & 22,41 & 2,60 \\
2015 & $-0,80$ & 1,00 & 0,32 & 0,20 & 18,65 & 34,36 & 27,62 & 1,92 \\
2016 & $-0,81$ & 1,00 & 0,30 & 0,24 & 15,65 & 33,87 & 27,41 & 3,04 \\
2017 & $-0,85$ & 0,94 & 0,30 & 0,20 & 24,03 & 39,75 & 32,53 & 2,50 \\
2018 & $-0,64$ & 0,87 & 0,28 & 0,18 & 22,47 & 44,33 & 35,92 & 2,87 \\
2019 & $-0,80$ & 0,90 & 0,29 & 0,19 & 18,49 & 36,19 & 30,12 & 2,12 \\
\hline
\end{tabular}

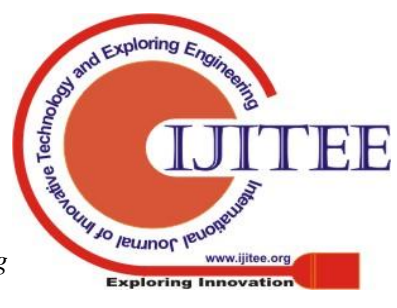



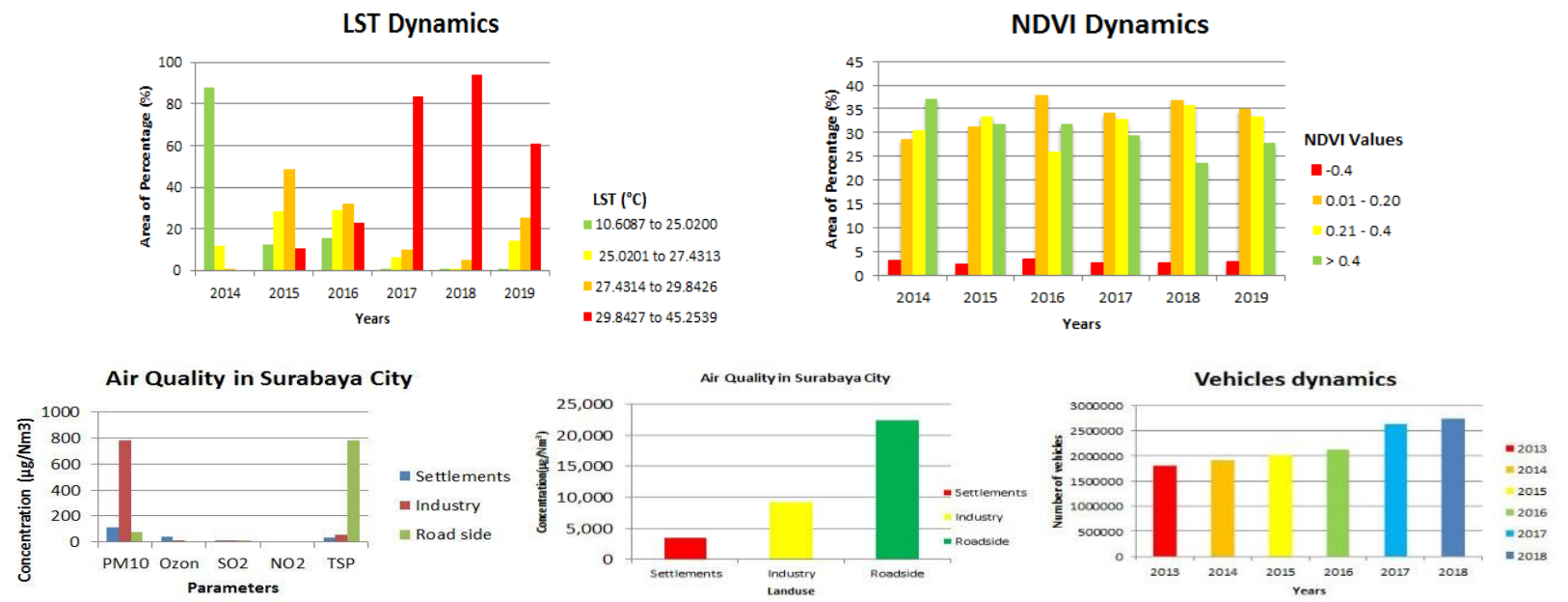

Fig. 2. Various dynamics of LST, NDVI, number of motor vehicles and air quality in the city of Surabaya

The concentration of the gas causes the atmospheric layer to thicken, then the gas absorbs and reflects the wave of solar radiation that is radiated from earth, then the resulting heat energy is stored on the earth surface. The relationship between these three parameters is the change of vegetation cover with awakened in urban areas will cause energy from solar radiation stored on the surface of the earth. It is supported by an increase in motor vehicles resulting in decreased air quality. This makes the surface temperature of the Earth in urban areas hotter than other regions or commonly called urban heat island phenomena.
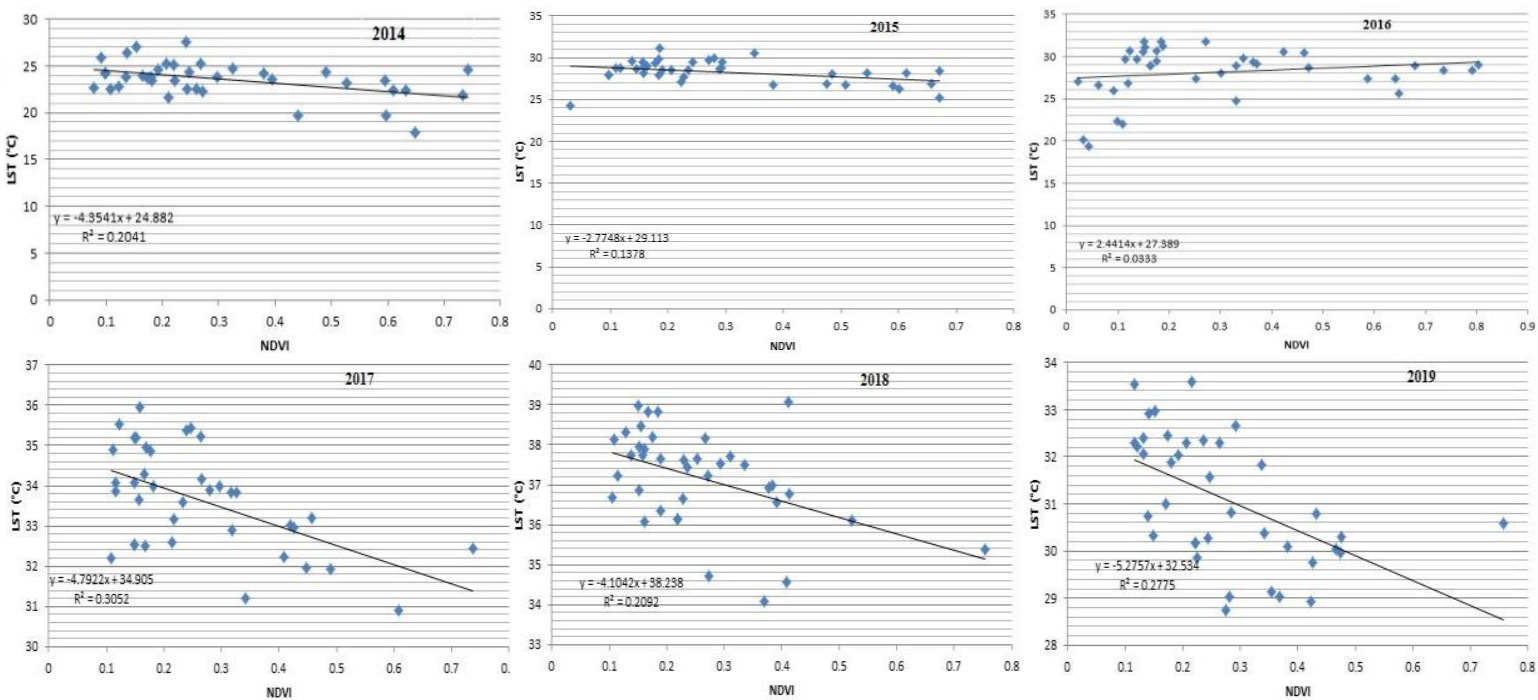

Fig. 3. Chart of a linear regression between LST and NDVI

Table-IV: The relationship of land surface temperature and NDVI.

\begin{tabular}{rrrrlll}
\hline \multicolumn{1}{l}{ Years } & R-stat & R-table & Samples & Description & Direction & Strength \\
\hline 2014 & -0.45176 & & & Significance & Negative & Intermediate-Strong \\
2015 & -0.37127 & & Significance & Negative & Weak \\
2016 & 0.182408 & 0.32 & 38 & Not & Positive & Very Weak \\
2017 & -0.55243 & & & Significance & Negative & Intermediate-Strong \\
2018 & -0.45736 & & & Negative & Intermediate-Strong \\
2019 & -0.52676 & & & Significance & Negative & Intermediate-Strong \\
\hline
\end{tabular}

The correlation coefficient between LST and NDVI per year from 2014 to 2019 in Table-IV. The correlation is negative in direction every year, but in the year 2016 is positive. It shows the higher the NDVI value, the LST is potentially getting down. The positive direction in the year 2016 is influenced by the presence of clouds so that the extraction of LST and NDVI is not maximal which results in the correlation direction being positive. The significance test indicates that each correlation obtained is significant by the average correlation has strong enough relationship strength, except in the year 2016.

Based on the regression chart in Fig. 4., the highest coefficient of determination was in the year 2017 with a value of $R^{2} 0.3052$ and $1: 1$ a negative directional plot. This shows that the predictor variable of the NDVI value has a $30.52 \%$ impact on LST decline and is significant,

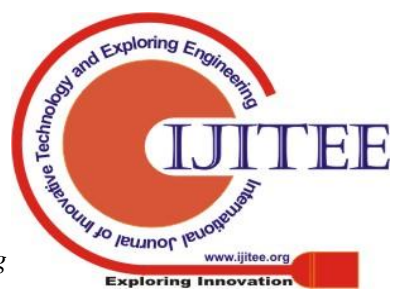


the remaining $69.48 \%$ is affected by other factors outside the predictive variable. The impact on rising surface temperatures is very complex among them environmental degradation, agricultural, health, and urban heat island. The solution is to do a reforestation of the city park and roadside, reforestation of the river, mangrove planting, strengthening the regulatory and increased public awareness [16].

\section{CONCLUSION}

The results showed the potential for having a relationship between vegetation density (NDVI), number of vehicles, and surface temperature (LST) associated with urban heat island. The vegetation density spatial distribution has decreased by $9.19 \%$ or 2989.8 hectares for 6 years. This is followed by the number of vehicles increased by 999,225 units from the year $2014-2019$, which is in line with the decline in urban air quality. Both factors affect the surface temperature that has an average hike of $3.95{ }^{\circ} \mathrm{C}$. The reforestation program, environmental monitoring, and regulatory reinforcement are crucial for tackling the urban heat island phenomenon.

\section{ACKNOWLEDGMENT}

The author thanked the financial support, data supply and laboratories to the Faculty of Mineral Technology, Environmental Geotechnical Laboratory Environment Engineering UPN "Veteran" Yogyakarta, USGS, and Remote Sensing Laboratory of Gadjah Mada University.

\section{REFERENCES}

1. Kikon. N, Singh. P, Singh. S. K, and Vyas. A, "Assessment of urban heat islands (UHI) of Noida City, India using multi-temporal satellite data,' Jornal of Sustainable Cities and Society," Volume 22, No 7, January. 2016, pp.19-28, doi:10.1016/j.scs.2016.01.005.

2. Bauman. P. R., An Urban Heat Island: Washington, D.C. New York: Departement of Geography State, University of New York College at Oneonta Oneonta, NewYork 13820 USA, 2001.

3. Sengkey. L, Sandri. F .J, Steeni. W, "Air pollution rate CO Traffic by Model prediction Air pollution," Journal of Media Engineering, Volume 1, No 2, 2011, pp. 119-126. (In Indonesia)

4. Ramanathan. V, Lian. M. S, Cess. R. D, "Increased Atmospheric CO2: Zonal and Seasonal Estimates of the Effect on the Radiation Energy Balance and Surface Temperature," Journal of Geophysical Research, Volume 84, Part C8, 1979, pp 4949 - 4958.

5. Southworth. J, "An Assessment of landsat TM band 6 Thermal data for analysing land cover in tropical dry forest region, International journal of remote sensing," Volume 25, No 4, 2004, pp. 689-706, Doi:10.1080/0143116031000139917.

6. Basar. U .G., S. Kaya, M. Karaka, "Evaluation of urban heat island in Istanbul using remote sensing technique," The International Archive of photogrammetry, remote sensing and Spatial information Sciences. Volume XXVII, Part B7. Beijing, 2008, pp. 971-976.

7. Valor. E, and V. Caselles, "Mapping Land Surface Emissivity from NDVI: Application to European, African, and south American areas," Journal of Remote sensing of environment, Volume 57, 1996, pp. 167-184.

8. Central Statistic Agency, City of Surabaya in the year 2018, Surabaya: Central Statistic Agency, ISSN: 0215 -6202, 2018, pp. 65 - 307. (In Indonesia)

9. Regional Revenue Agency East Java Province, Number of motor vehicles, BAPENDA, 2017, URL: https://www.dipendajatim.go.id. (In Indonesia)

10. 10.Vlassova. L, Perez-Cabello. F, Nieto. H, Martin. P, Riano. D, and de la Riva. J, “Assessment of Methods for Land Surface Temperature Retrieval from Landsat-5 TM Images Applicable to Multiscale Tree-Grass Ecosystem Modeling," Journal of Remote Sens, Volume 6, 2014 pp.4345-4368.
11. United States Geological Survey (USGS), Landsat 8 (L8) Data Users Handbook, LSDS-1574.2015. Version 1.0, 2015, URL: http://landsat.usgs.gov/Landsat8 Using Product.php.

12. Tan. K. C, Lim, H. S, Jafri. M. Z. M, Abdullah. K, "Study on Land Surface Temperature Based on Landsat Image Over Penang Island, Malaysia," Proceeding of Sixth International Conference on Computer Graphics, Imaging and Visualization. Tianjin: IEEE, 2009, URL: https:// 10.1109/CGIV.2009.94.

13. Qin. Z. H, Li. W, Xu. B, Chen. Z, and Liu. J, Remote Sensing for Land and Resources, 3, 2004, pp. 28-42.

14. Sugiyono, Business Research Methods, Bandung: CV Alfabeta Press, 2008, pp. 124 - 126. (in Indonesia)

15. Anjarwati., et al, Environmental Management Performance Information Document (DIKPLHD), Surabaya: Environment Office, East Java Province, 2017, pp. 75-206. (in Indonesia)

16. Peng. S, et.al, "Afforestation in China Cools Local Land Surface Temperature," Proceedings of Natl. Acad,Sci.USA, Feb 24. 2014, Volume 111, No 8, 2014, pp. 2915 - 2919, Available: https://dx.doi.org/10.1073\%2Fpnas.1315126111.

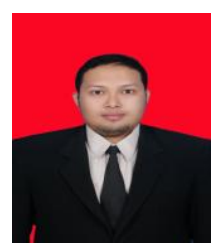

\section{AUTHORS PROFILE}

Mohammad Abdul Khafid, $\mathrm{He}$ is student in Department of Environmental Engineering, Faculty of Mineral Technology, Universitas Pembangunan Nasional Veteran Yogyakarta. He was active as an environmental geotechnical laboratory assistant and was active in scientific paper contributions at national and international conferences focusing on the theme of the terrestrial environment. Research coverage of journal publication and scopus indexed proceedings are predictions of GIS-based landslide in Gunungkidul regency, analysis of urban heat island with remote sensing in Cirebon and Surabaya, environmental carrying capacity as tourism area in Gunungkidul, impact on global warming to sea level rise in south coast Yogyakarta, geosite assessment as geotourism in Semarang and the utilization of Gunungkidul natural zeolite for corrosion resistance. $\mathrm{He}$ is active as a member of various environmental organizations such as IMTLI Reg Yogyakarta and KOPHI Yogyakarta. Interested in the field of research on global warming, environmental carrying capacity and disaster management.

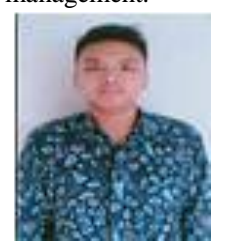

Aditya Pandu Wicaksono, MSc. He has been involving in disaster management related project since he graduated from Faculty of Geography, Gadjah Mada University. He has extensive experience in community based risk mapping and modelling land use change. He was team member to develop disaster management plan for several areas in Indonesia such as Central Java Province (Magelang and Jepara), North morowali, west papua, and Eas Kalimantan Province (Bontang). He also actively participates in hazard mapping related projects. He was once member of emergency response team when he worked for Oxfam GB. Aditya is currently a lecturer at University of Pembangunan Nasional "Veteran" in Yogyakarta and active researcher at the university's Research Centre for Disaster Management (Pusat Studi Manajemen Bencana).

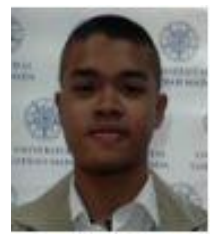

Bayu Elwantyo Bagus Dewantoro is a college student of the Department of Geographic Information Science, Faculty of Geography, Gadjah Mada University. Ever contributed to the National Seminar III of Geography, Gadjah Mada University and National Seminar on Fisheries Management Lombok, West Nusa Tenggara. Interested in the areas of urban research, vegetation, atmosphere, and spatial modeling using the integration of remote sensing techniques and geographic information systems. 